\title{
COMPARATIVE STUDY ON THE EFFECTS OF LYCOPENE AND SAFFRON ON DOXORUBICIN-INDUCED CARDIOTOXICITY IN ADULT MALE ALBINO RATS: A HISTOLOGICAL AND BIOCHEMICAL ASSESSMENT
}

\author{
Nashwa Mohamad Mohamad Shalaby and Wafaa Ibrahim Soliman \\ Department of Forensic Medicine and Clinical Toxicology, Faculty of Medicine, Zagazig \\ University, Egypt
}

\begin{abstract}
Background: Doxorubicin (DOX), is one of the most widely-used chemotherapeutic drugs. Despite its broad therapeutic efficacy, clinical studies have reported that, the major limiting factor of DOX chemotherapy is its significant cardiotoxic effects, which often results in irreversible degenerative cardiomyopathy and heart failure. Lycopene and saffron are powerful antioxidants against free radicals and oxidative attacks. Aim of the work: the aim of this study was to investigate and compare the protective effects of tomato Lycopene (LYC) and saffron against DOX induced cardiotoxicity in adult male rats. Material and methods: the study was conducted on 48 adult male albino rats, divided into six groups; group I served as (Control group), group II (Lycopene treated group), group III (Saffron treated group), group IV (Doxorubicin treated group), groupV (Doxorubicin and Lycopene treated group), groupVI (Doxorubicin and saffron treated group). At the end of experiment, all rats were sacrificed and their blood and heart tissues were subjected to biochemical analysis, while the remaining heart tissues were stained for histopathological study. Results: Doxorubicin co-administration with either tomato LYC or saffron showed significant improvements of all studied parameters with the superiority of LYC as regards cardiac enzyme parameters and cardiac troponin. Recommendations: Human trials should be carried out to establish the potential protective effects of lycopene and saffron. Future experiments are required to evaluate the possible protective molecular mechanisms of lycopene and saffron against DOX-induced cardiotoxicity

Keywords: Doxorubicin, Lycopene, Saffron, cardiotoxicty.
\end{abstract}

\section{INTRODUCTION:}

Doxorubicin (Dox),

an

anthracycline chemotherapeutic drug, is used in treatment of many solid tumors as well as malignant hematologic diseases. Despite its broad therapeutic efficacy, clinical studies showed that the major limiting factor of DOX chemotherapy is its cardiotoxic effects, which often leads to irreversible degenerative cardiomyopathy with heart failure (Tokarska-Schlattner et al., 2006; Octavia et al., 2012). Even at lower doses, some patients develop heart disease many years after treatment (Lipshultz et al., 2013).

Several potential mechanisms of DOX-induced cardiotoxicity were suggested, and after comprehensive basic and clinical investigation, the free radical hypothesis was acknowledged (Corna et al., 2004; Shi et al., 2011; Ichikawa et al 2014).

Considering that the heart tissues is vulnerable to free radicals due to less development of antioxidant defense 
mechanisms (Doroshow et al., 1980), cellular injury can be attributed to DOX-induced oxidative stress. As free radicals play a basic role in DOXinduced cardiotoxicity, antioxidants could protect the heart tissues against DOX-toxicity (Razmaraii et al., 2016 C).

Among several studies attempt to decrease cardiotoxic effect of this valuable drug, scavenging of ROS by natural antioxidants is considered as favorable cardioprotective against DOX-induced cardiotoxicity both in vitro and in vivo (Mohamad et al., 2009; Li et al., 2010).

Lycopene ( $\psi, \psi$-Carotene) (LYC) is a natural carotenoid, which can be found in ripped tomato fruit, watermelon as well as pink grapefruit. Several studies proved its properties in decreasing many chronic or inflammatory diseases (Bramley, 2000].

Lycopene has good antioxidant properties include scavenging singlet oxygen and free radical (Johnson, 2002). Recently, it has been used as a food additive as well as a natural antioxidant. Additionally, LYC exhibited potent neuroprotective, antiinflammatory, anti-proliferative, maintenance of normal cell metabolism, cognition enhancing properties and regulating blood lipid metabolism (Kumar et al 2009; Maiani, et al., 2009; Ried and Fakler, 2011; Sachdeva and Chopra, 2015 ;Datta et al., 2016).

Crocus sativus L. known as saffron belongs to the Iridaceae family and has a dried red stigma, which is used in folk medicine for many purposes including anti-spasmodic, eupeptic, gingival, sedative, anti-catarrhal, carminative, diaphoteric, expectorant, stimulant, stomachic, aphrodisiac and emmenagogue effects (Shen and Qian, 2006).

Saffron contains many pharmacologically active compounds as crocin, picrocrocin and safranal. Crocin, a water-soluble carotenoid has anticarcinogen (Fernández, 2006), radical scavenging (Assimopoulou et al., 2005), anti-hyper lipidemic (Soeda et al., 2007) and memory improving actions (Hosseinzadeh and Ziaei, 2006).

Papandreou et al., (2006) stated that, Saffron antioxidant effect was compared with other vegetables rich in carotenoids antioxidant (carrots and tomatoes), and that, the extract of $\mathrm{C}$. sativus stigmas had stronger antioxidant effect than carrots and tomatoes.

Therefore, with this background on Doxorubicin, lycopene, and saffron, we aimed to investigate and compare the possible beneficial effects of lycopene, and saffron against Doxorubicininduced cardiotoxicity in adult male albino rats.

\section{MATERIALS \& METHODS:}

\section{Ethical Consideration of Study}

Experimental procedures as well as the use of laboratory animals were approved by the Animal Research Committee in Zagazig University. Painless procedures were conducted. Animal housing and handling were ethically considered.

\section{Animals}

In this study 48 male SpragueDawley mature albino rats, 200-220 g weight each, were used. Animals were fed ad libitum and housed in pairs in steel cages, having a temperaturecontrolled environment $\left(22 \pm 2^{\circ} \mathrm{C}\right)$ with $12 \mathrm{~h}$ light/dark cycles. 
Chemicals

Doxorubicin $\mathrm{HCl}$ (Adriblastina ${ }^{\circledR}$ ) (50mg) was obtained from Pharmacia S.P.A. Inc., Milan, Italy.

Lycopene: Tomatoes (Solanum lycopersicum L., Solanaceae were purchased from local commercial sources. The botanical authentication and extraction were done at the Department of Pharmacognosy, Faculty of Pharmacy, Zagazig University according to Luo and Wu (2011).

The obtained LYC extract weighed 4 grams. This amount was prepared in $80 \mathrm{~mL}$ of corn oil (50 mg-ml) and preserved in a refrigerator at $4 \mathrm{C}$ in a dark container to avoid oxidation of LYC.

Saffron manufactured by Sigmaaldrich company,Louis st.,USA, and purchased from Sigma-Egypt.

\section{Experimental Protocol}

Animals were randomly divided into 6 groups.

Group I (control group): contains 18 rats and is further divided into 3 equal subgroups as follows:

- Ia $\rightarrow$ negative control - received regular diet and water.

- $\mathrm{Ib} \rightarrow$ saline treated group received $1 \mathrm{ml}$ saline $(0.9 \%)$ once daily.

- Ic $\rightarrow$ corn oil treated group received $0.5 \mathrm{~mL}$ corn oil daily (used for preparation of oral suspension of LYC) by oral gavage.

- Group II (Lycopene treated group) contains 6 rats; each received LYC in a dose of $200 \mathrm{mg} / \mathrm{kg} /$ day for 4 weeks by oral gavage (StacewiczSapuntzakis and Bowen, 2005).

- Group III (Saffron treated group) contains 6 rats; each received saffron in a dose of $20 \mathrm{mg} / \mathrm{kg}$ once a daily for 4 weeks dissolved in $1 \mathrm{ml}$ saline (0.9\%) (Goyal et al., 2010).

-Group IV (Doxorubicin treated group) contains 6 rats; each received DOX in a dose of $2.5 \mathrm{mg} / \mathrm{kg}$ dissolved in normal saline by intra muscular route in the form of 6 injections over a period of 2 weeks to end up in a total cumulative dose of $15 \mathrm{mg} / \mathrm{kg}$. (Koti et al., 2009).

-GroupV (Doxorubicin and Lycopene treated group) contains 6 rats; each received lycopene for 4 weeks starting 2 weeks before DOX administration and then for two additional weeks concomitantly with DOX administration at the same dose levels in the aforementioned groups.

-GroupVI (Doxorubicin and saffron treated group) contains 6 rats; each received saffron for 4 weeks starting 2 weeks before DOX administration and then for two additional weeks concomitantly with DOX administration at the same dose levels in the aforementioned groups.

Rats' body weight was recorded daily, At the end of experiment, blood samples were obtained then all animals were scarified under light ether anesthesia, serum was collected and stored at $-20{ }^{\circ} \mathrm{C}$ until measurement. Hearts were removed and weighed then stained for histopathological studies.

Method used for measurement of blood pressure and heart rate:

Principle:

Non-invasive Blood Pressure measurement was done according to NIBP250 User's Guide (2013). During occlusion cuff inflation, tail blood experiences 3 distinct phases.

1. Phase I occurs once the cuff has been inflated to its maximum pressure. At this point, the pressure is so great that it occludes the artery and no blood passes. It is then followed by the release of this pressure. This phase is represented by the flat-line before the 
systolic point.

2. Phase II occurs once the pressure drops below the animal's systolic blood pressure. It is at this time that blood can force its way through the partially occluded artery and generate a signal for the sensor cuff. This phase is represented on the graph by the ascending waveform between the systolic and diastolic points.

3. Phase III takes place when the pressure is not enough to restrict blood flow at all, and the waveform from the signal cuff resumes its regular form and amplitude. The high-amplitude portions of the waveform at the beginning and end represent the animal's heart rate (Bunag et al., 1982).

\section{Biochemical parameters:}

Venous blood samples were obtained from animals by means of capillary glass tubes from the retroorbital plexus under light ether anesthesia (Semler, 1992).

The collected blood was used to measure the following parameters:

\section{- Oxidative marker:}

1-MDA (nmol/ $\mathrm{ml}$ ) that was assayed colorimetrically according to Ohkawa and colleagues (1979).

2- GSH (ng/ml) that was assayed colorimetrically according to Beutler and colleagues (1963).

3-Catalase activity $(\mathrm{U} / \mathrm{ml})$ that was assayed colorimetrically according to Aebi, (1983).

- Cardiac Troponin I: was measured according to Collinson and fellow researchers (2001).

- Assessement of serum level of cardiac marker enzymes:

Serum level of lactate dehydrogenase (LDH) and creatinine$\mathrm{MB}$ isoenzyme (CK-MB) enzymes were determined according to guidelines of some locally available commercial kits using previously described principles of Buhl and Jackson, (1978) and Wu and Bowers, (1982).

\section{- Tissue parameters:}

Hearts were immediately dissected out and grossly inspected to assess any gross abnormalities then washed with cold normal saline and used for histopathological study.

\section{Light microscope examination:}

They were fixed in 10\% formalin solution. After which, tissues were embedded in paraffin blocks and processed into $5 \mathrm{u}$. thickness sections. They were stained by Hematoxyin and Eosin (Horobin and Bancroft, 1998) and examined using light microscope.

\section{Statistical analysis}

Data were analyzed by Statistical Package of Social Science (SPSS), software version 22.0 (SPSS Inc., 2013).

\section{RESULTL}

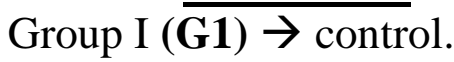

control.

- Group Ia (G1a) $\rightarrow$ negative

- Group Ib (G1b) $\rightarrow$ saline treated group.

- Group Ic (G1c) $\rightarrow$ corn oil treated group.

Group II (GII) $\rightarrow$ Lycopene-treated group.

Group III (GIII) $\rightarrow$ Saffron-treated group.

Group IV (GIV) $\rightarrow$ Doxorubicintreated group.

GroupV $(\mathbf{G V}) \rightarrow$ Doxorubicin and Lycopene treated group.

GroupVI (GVI) $\rightarrow$ Doxorubicin and saffron treated group.

Biochemical findings among G1a, G1b, G1c, GII and GIII were not statistically significant as regards all studied parameters (Table 1, 2, 3). So, 
G1a was used as the control group for comparison with other treated groups.

Findings confirmed that body and heart weights decreased after DOX treatment but increased after lycopene and saffron treatment. (Table 4, 7 ).

Doxorubicin treated group showed increased cardiac troponin I, LDH and CPK. Furthermore, disturbance of oxidative marker in heart tissue was reversed by supplementation of lycopene or saffron with superiority of lycopene (Table 5, 8).

A significant decrease in the heart rate was detected in the DOX-treated group. Also, Dox caused a decrease in the systolic, diastolic, mean BP which was reversed by lycopene or saffron with superiority of lycopene (Table 6, 9).

\section{Histopathological result:}

Left ventricles of GI showed normal myocardial architecture (Fig.1). While histopathogical examination of GIV revealed myocardial cell damage, necrosis, and massive interstitial hemorrhage (Figs.2).

Upon supplemation of either lycopene or saffron there was paritial reversal of these pathological changes (Fig.3, 4).

Table (1): Statistical comparison among negative control (G1a), saline (G1b), corn oil (G1c), lycopene (GII) and saffron (GIII) treated groups as body and cardiac weights using ANOVA test.

\begin{tabular}{|l|l|l|l|l|l|l|l|}
\hline & GIa & GIb & GIc & GII & GIII & F & P \\
\hline Body & $199.32 \pm$ & $198.11 \pm$ & $197.98 \pm$ & $199.02 \pm$ & $198.91 \pm$ & $\mathbf{1 . 7 2 5}$ & $>0.05$ \\
wt & 1.02 & 1.02 & 1.01 & 1.22 & 1.21 & & \\
\hline Heart & $0.90 \pm 0$. & $0.91 \pm$ & $0.90 \pm$ & $0.92 \pm$ & $0.91 \pm$ & $\mathbf{1 . 3 8 8}$ & $>0.05$ \\
wt & 0201 & 0.021 & 0.010 & 0.011 & 0.022 & & \\
\hline
\end{tabular}

NB All values are expressed as Mean \pm+ SD $\quad$ N: Number of rats in each group $=6$ rats SD: standard deviation P: $<0.05$ significant

Table (2): Statistical comparison among negative control (GIa), saline (GIb), corn oil (GIc), lycopene (GII) and saffron (GIII) treated groups as regard mean values of LDH, CBK, cardiac troponin I, oxidative stress markers using ANOVA test.

\begin{tabular}{|c|c|c|c|c|c|c|c|}
\hline & GIa & GIb & GIc & GII & GIII & $\mathrm{F}$ & $\mathrm{P}$ \\
\hline LDH & $\begin{array}{c}369.12 \pm \\
4.91\end{array}$ & $\begin{array}{c}367.99 \pm \\
4.95\end{array}$ & $\begin{array}{c}368.55 \pm \\
4.85\end{array}$ & $\begin{array}{c}365.95 \pm \\
3.99\end{array}$ & $\begin{array}{c}366.45 \pm \\
3.45\end{array}$ & 0.556 & $>0.05$ \\
\hline CBK(MB) & $\begin{array}{c}337.98 \pm \\
3.89\end{array}$ & $\begin{array}{l}336 \pm \\
3.45\end{array}$ & $\begin{array}{c}335.99 \pm \\
4.12\end{array}$ & $\begin{array}{c}336.55 \pm \\
4.44\end{array}$ & $\begin{array}{c}335.99 \pm \\
3.85\end{array}$ & 0.283 & $>0.05$ \\
\hline $\begin{array}{l}\text { Cardiac } \\
\text { treponin I }\end{array}$ & $\begin{array}{c}50.33 \pm 4 \\
35\end{array}$ & $\begin{array}{c}49.35 \pm \\
4.33\end{array}$ & $\begin{array}{c}\mathbf{5 1 . 1 2 \pm} \\
3.44\end{array}$ & $\begin{array}{l}49.55 \pm \\
\mathbf{4 . 0 5}\end{array}$ & $\begin{array}{c}48.99 \pm \\
\mathbf{3 . 0 9}\end{array}$ & 0.290 & $>0.05$ \\
\hline $\begin{array}{c}\text { MDA } \\
(\mathrm{nmol} / \mathrm{ml})\end{array}$ & $\begin{array}{c}159.55 \pm \\
50.75\end{array}$ & $\begin{array}{c}160.05 \pm \\
50.63 \\
\end{array}$ & $\begin{array}{c}175.71 \pm \\
55.23\end{array}$ & $\begin{array}{c}166.98 \pm \\
54.95 \\
\end{array}$ & $\begin{array}{c}165.55 \pm \\
53.55 \\
\end{array}$ & 0.091 & $>0.05$ \\
\hline $\begin{array}{c}\text { GSH } \\
(\mathrm{ng} / \mathrm{ml})\end{array}$ & $\begin{array}{c}0.90 \pm \\
0.28 \\
\end{array}$ & $\begin{array}{c}0.89 \pm \\
0.27\end{array}$ & $\begin{array}{c}0.85 \pm \\
0.25\end{array}$ & $\begin{array}{c}0.87 \pm \\
0.27\end{array}$ & $\begin{array}{c}0.86 \pm \\
0.28\end{array}$ & 0.035 & $>0.05$ \\
\hline $\begin{array}{l}\text { catalase activity } \\
(\mathrm{U} / \mathrm{ml}):\end{array}$ & $\begin{array}{l}5.19 \pm \\
0.85\end{array}$ & $\begin{array}{l}5.38 \pm \\
0.86\end{array}$ & $\begin{array}{c}4.98 \pm \\
0.74\end{array}$ & $\begin{array}{l}5.00 \pm \\
0.64\end{array}$ & $\begin{array}{l}5.15 \pm \\
0.75\end{array}$ & 0.265 & $>0.05$ \\
\hline
\end{tabular}

Values are expressed as Mean \pm SD $\quad$ SD: standard deviation $\quad$ P: $<0.05$ significant 
Table (3): Statistical comparison among negative control (GIa), saline (GIb), corn oil (GIc), lycopene (GII) and saffron (GIII) treated groups as regards SBP, DBP, MBP and HR using ANOVA test.

\begin{tabular}{|l|l|l|l|l|l|l|l|}
\hline & GIa & GIb & GIc & GII & GIII & F & P \\
\hline SBP & $136.6 \pm$ & $135 \pm$ & $135.4 \pm$ & $132.4 \pm$ & $135 \pm$ & $\mathbf{0 . 3 6 1}$ & $>0.05$ \\
& 5.399 & 6.498 & 6.398 & 6.132 & 6.733 & & \\
\hline DBP & $114.2 \pm$ & $113.1 \pm$ & $115.2 \pm$ & $114.3 \pm$ & $113.2 \pm$ & $\mathbf{0 . 1 1 8}$ & $>0.05$ \\
& 6.663 & 5.971 & 6.143 & 6.144 & 5.972 & & \\
\hline MBP & $106.3 \pm$ & $106.4 \pm$ & $105.3 \pm$ & $107.2 \pm$ & $106.9 \pm$ & $\mathbf{0 . 1 6 8}$ & $>0.05$ \\
& 3.020 & 3.022 & 5.021 & 5.888 & 4.023 & & \\
\hline HR & $166.9 \pm$ & $167.8 \pm$ & $166.1 \pm$ & $116.8 \pm$ & $166.5 \pm$ & $\mathbf{0 . 0 1 9}$ & $>0.05$ \\
& 10.493 & 9.493 & 12.069 & 12.055 & 11.069 & & \\
\hline
\end{tabular}

Values are expressed as Mean \pm SD SD: standard deviation P: $<0.05$ significant SBP: systolic blood pressure DBP: diastolic blood pressure MBP: mean blood pressure HR: heart rate

Table (4): Statistical comparison among negative control (GIa), Doxorubicin (GIV) treated, Doxorubicin and lycopene $(\mathrm{GV})$ treated and Doxorubicin and saffron (GVI) treated groups as regards body weight and cardiac weight using ANOVA test

\begin{tabular}{|l|l|l|l|l|l|l|}
\hline & GIa & GIV & GV & GVI & F & P \\
\hline $\begin{array}{l}\text { Body } \\
\text { wt }\end{array}$ & $199.32 \pm$ & $168.02 \pm 1.03$ & $189.30 \pm 1.04$ & $\begin{array}{l}180.05 \pm \\
1.01\end{array}$ & $\mathbf{1 , 0 1 5 . 7 2 5}$ & $<0.0001^{*}$ \\
\hline $\begin{array}{l}\text { Heart } \\
\text { wt }\end{array}$ & $0.90 \pm 0.0201$ & $0.65 \pm$ & $0.84 \pm 0.0121$ & $0.77 \pm$ & $\mathbf{2 3 4 . 8 9 1}$ & $<0.0001^{*}$ \\
\hline
\end{tabular}

$\begin{array}{lll}\text { Values are expressed as Mean } \pm \text { SD } & \text { SD: standard deviation } & \text { P: }<0.05 \text { significant }\end{array}$

Table (5): Statistical comparison among negative control (GIa), Doxorubicin (GIV) treated, Doxorubicin and lycopene $(\mathrm{GV})$ treated and Doxorubicin and saffron (GVI) treated groups as regards mean values of LDH, CBK, Cardiac troponin I, oxidative stress markers using ANOVA test

\begin{tabular}{|c|c|c|c|c|c|c|}
\hline & GIa & GIV & GV & GVI & $\mathbf{F}$ & $\mathbf{P}$ \\
\hline LDH & $\begin{array}{l}369.12 \\
\pm 4.91\end{array}$ & $\begin{array}{l}425.45 \pm \\
4.54\end{array}$ & $\begin{array}{l}380.55 \pm \\
2.99\end{array}$ & $\begin{array}{c}398.85 \pm \\
3.98\end{array}$ & 208.519 & $<0.0001 *$ \\
\hline CBK & $\begin{array}{l}337.98 \\
\pm 3.89\end{array}$ & $\begin{array}{c}398.85 \pm \\
3.55\end{array}$ & $\begin{array}{l}345.54 \pm \\
2.45\end{array}$ & $\begin{array}{l}358.22 \pm \\
2.98\end{array}$ & 414.173 & $<0.0001 *$ \\
\hline $\begin{array}{l}\text { Cardiac } \\
\text { treponin I }\end{array}$ & $\begin{array}{l}50.33 \pm 4 \\
.35\end{array}$ & $\begin{array}{l}89.16 \pm \\
17.28\end{array}$ & $\begin{array}{c}60.15 \pm \\
\mathbf{1 8 . 3 3}\end{array}$ & $\begin{array}{l}\mathbf{6 6 . 8 5} \pm \\
17.18\end{array}$ & 6.876 & \\
\hline $\begin{array}{c}\text { MDA (nmol/ } \\
\mathrm{ml})\end{array}$ & $\begin{array}{r}159.55 \\
+50.75\end{array}$ & $\begin{array}{l}315.66+ \\
95.45\end{array}$ & $\begin{array}{l}181.35 \\
55.65\end{array}$ & $\begin{array}{l}211.88+ \\
67.55\end{array}$ & 5.926 & $\begin{array}{l}(\mathbf{0 . 0 0 5}) \\
<0.05^{*}\end{array}$ \\
\hline GSH (ng/ml & $\begin{array}{c}0.90+ \\
0.28\end{array}$ & $\begin{array}{c}0.32+ \\
0.10\end{array}$ & $0.85+0.12$ & $0.74+0.23$ & 10.712 & $<0.0001 * * *$ \\
\hline $\begin{array}{c}\text { catalase } \\
\text { activity }(\mathrm{U} / \mathrm{ml})\end{array}$ & $\begin{array}{c}5.19+ \\
0.85\end{array}$ & $\begin{array}{c}2.44+ \\
0.72\end{array}$ & $3.99+0.75$ & $3.40+0.55$ & 15.080 & $<0.0001 * * *$ \\
\hline
\end{tabular}

Values are expressed as Mean \pm SD SD: standard deviation $P:<0.05$ significant $P:<0.0001$ highly significant 
Table (6): Statistical comparison among negative control (GIa), Doxorubicin (GIV) treated, Doxorubicin and lycopene $(\mathrm{GV})$ treated and Doxorubicin and saffron (GVI) treated groups as regards mean values of SBP, DBP, MBP and HR using ANOVA test

\begin{tabular}{|l|l|l|l|l|l|l|}
\hline & GIa & GIV & GV & GVI & F & P \\
\hline SBP & $136.6 \pm$ & $100 \pm$ & $125.4 \pm$ & $115.4 \pm$ & $\mathbf{6 5 . 8 6 2}$ & $>0.0001$ \\
& 5.399 & 5.448 & 3.212 & 4.338 & & \\
\hline DBP & $114.2 \pm$ & $85.1 \pm$ & $104.3 \pm$ & $95.2 \pm$ & $\mathbf{2 9 . 7 7 3}$ & $>0.0001$ \\
& 6.663 & 4.981 & 4.122 & 6.221 & & \\
\hline MB & $106.3 \pm$ & $80.4 \pm$ & $99.2 \pm$ & $90.3 \pm 4$ & $\mathbf{6 5 . 7 8 1}$ & $>0.0001$ \\
P & 3.020 & 3.125 & 3.285 & .021 & & \\
\hline HR & $166.9 \pm$ & $120.8 \pm$ & $155.8 \pm$ & $140.1 \pm$ & $\mathbf{2 2 . 5 5 4}$ & $>0.0001$ \\
& 10.493 & 10.495 & 9.155 & 11.069 & & \\
\hline
\end{tabular}

Values are expressed as Mean \pm SD SD: standard deviation P: $<0.05$ significant P: $<0.0001$ highly significant SBP: systolic blood pressure DBP: diastolic blood pressure MBP: mean blood pressure HR: heart rate

Table (7): Least significant difference test (LSD) for comparison of the changes of the mean values of body weight and cardiac weight in-between groups.

\begin{tabular}{|c|c|c|c|c|}
\hline Group & Control & $\begin{array}{l}\text { Doxorubicin } \\
\text { treated group }\end{array}$ & $\begin{array}{l}\text { Doxorubicin } \\
\text { and Lycopene } \\
\text { treated group }\end{array}$ & $\begin{array}{l}\text { Doxorubicin } \\
\text { and Saffron } \\
\text { treated group }\end{array}$ \\
\hline \multirow{3}{*}{$\begin{array}{l}\text { Body weight: } a=\text { versus control } \\
b=\text { versus Doxorubicin treated group } \\
\mathrm{c}=\text { versus Doxorubicin and Lycopene } \\
\text { treated group }\end{array}$} & & $0.94 \mathrm{a}$ & $0.94 \quad \mathrm{a}$ & $0.0083 * *$ a \\
\hline & & 0.24 & & 0.94 \\
\hline & \multicolumn{4}{|c|}{$0.0008 * * \mathrm{c}$} \\
\hline \multirow{3}{*}{$\begin{array}{l}\text { Heart weight: } a=\text { versus control } \\
b=\text { versus Doxorubicin treated group } \\
c=\text { versus Doxorubicin and Lycopene } \\
\text { treated group }\end{array}$} & & $0.82 \mathrm{a}$ & $<0.0001 * *$ a & $<0.0001 * *$ a \\
\hline & & $<0.0001 * *$ & & $0.119 \mathrm{~b}$ \\
\hline & \multicolumn{4}{|c|}{$<0.0001 * * \mathbf{c}$} \\
\hline
\end{tabular}

Number of sacrificed rats for each group was 6 rats. *: significant $(\mathbf{p}<0.05) \quad * *$ : highly significant $(\mathbf{p}<0.01)$. NS: non-significant. 
Table (8): Least significant difference test (LSD) for comparison of the changes of the mean values of $\mathrm{LDH}$ and $\mathrm{CBK}$ in-between groups.

\begin{tabular}{|c|c|c|c|c|}
\hline $3^{2}$ & Control & $\begin{array}{l}\text { Doxorubicin } \\
\text { treated group }\end{array}$ & $\begin{array}{l}\text { Doxorubicin } \\
\text { and Lycopene } \\
\text { treated group }\end{array}$ & $\begin{array}{l}\text { Doxorubicin } \\
\text { and Saffron } \\
\text { treated group }\end{array}$ \\
\hline \multirow{3}{*}{$\begin{array}{l}\text { LDH: } a=\text { versus control } \mathrm{b}=\mathrm{versus} \\
\text { Doxorubicin treated group } \\
\mathrm{c}=\text { versus Doxorubicin and Lycopene } \\
\text { treated group }\end{array}$} & \multicolumn{2}{|c|}{$0.67 \mathrm{a}$} & $<0.0001 * *$ a & $<0.0001 * *$ a \\
\hline & \multicolumn{3}{|c|}{$<0.0001 * * \quad$ b } & 0.079 \\
\hline & \multicolumn{4}{|c|}{$<0.0001 * * \mathrm{c}$} \\
\hline \multirow{3}{*}{$\begin{array}{l}\text { CBK: a=versus control } \mathrm{b}=\mathrm{versus} \\
\text { Doxorubicin treated group } \\
\mathrm{c}=\text { versus Doxorubicin and Lycopene } \\
\text { treated group }\end{array}$} & \multicolumn{2}{|r|}{0.93 a } & $<0.0001 * *$ a & $<0.0001 * * a$ \\
\hline & \multicolumn{3}{|c|}{$0.42 \quad b$} & $0911 \mathrm{~b}$ \\
\hline & \multicolumn{4}{|c|}{$<0.0001 * * \mathbf{c}$} \\
\hline
\end{tabular}

Number of sacrificed rats for each group was 6 rats.

*: significant $(\mathrm{p}<0.05) \quad * *$ : highly significant $(\mathrm{p}<0.01)$.

NS: nonsignificant.

Table (9): Least significant difference test (LSD) for comparison of the changes of the mean values of cardiac troponin I and oxidative stress markers in-between groups.

\begin{tabular}{|c|c|c|c|}
\hline Parameter & Control $\begin{array}{l}\begin{array}{l}\text { Doxorubicin } \\
\text { treated } \\
\text { group }\end{array} \\
\end{array}$ & $\begin{array}{l}\text { Doxorubicin } \\
\text { and Lycopene } \\
\text { treated group }\end{array}$ & $\begin{array}{l}\text { Doxorubicin } \\
\text { and Saffron } \\
\text { treated group }\end{array}$ \\
\hline \multirow{3}{*}{$\begin{array}{l}\text { Cardiac treponin I } \\
\mathrm{a}=\text { versus control } \\
\text { Doxorubicin } \quad \text { treated }\end{array}$} & $0.0016 * *$ a & $0.69 \mathrm{a}$ & $0.277 \mathrm{a}$ \\
\hline & \multicolumn{2}{|l|}{$0.019 * \mathbf{b}$} & 0.089 \\
\hline & \multicolumn{3}{|r|}{$0.87 \quad \mathrm{c}$} \\
\hline \multirow{3}{*}{ 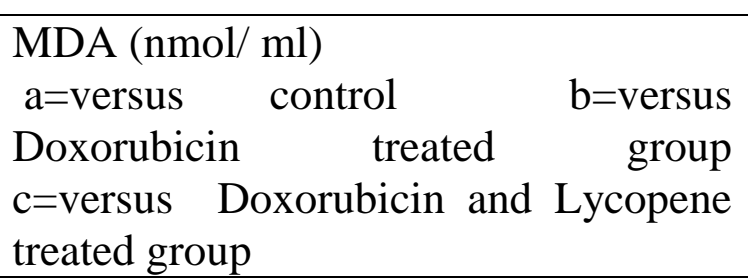 } & \multicolumn{2}{|l|}{$0.0047 * * a$} & $0.57 \mathrm{a}$ \\
\hline & \multicolumn{2}{|l|}{$0.016 *$ b } & $0.077 \mathrm{~b}$ \\
\hline & \multicolumn{3}{|c|}{$0.87 \mathrm{c}$} \\
\hline \multirow{3}{*}{$\begin{array}{l}\text { GSH }((\mathrm{ng} / \mathrm{ml}) \\
\mathrm{a}=\mathrm{versus} \text { control } \\
\begin{array}{l}\text { Doxorubicin treated } \\
\mathrm{c}=\text { versus Doxsus } \\
\text { treated group }\end{array}\end{array}$} & \multicolumn{2}{|l|}{$0.0003 * *$ a } & $0.51 \mathrm{a}$ \\
\hline & \multicolumn{2}{|r|}{$\mathbf{0 . 0 0 0 8}^{* *} \mathbf{b}$} & $0.007 * * b$ \\
\hline & \multicolumn{3}{|r|}{$0.77 \mathrm{c}$} \\
\hline \multirow{3}{*}{ 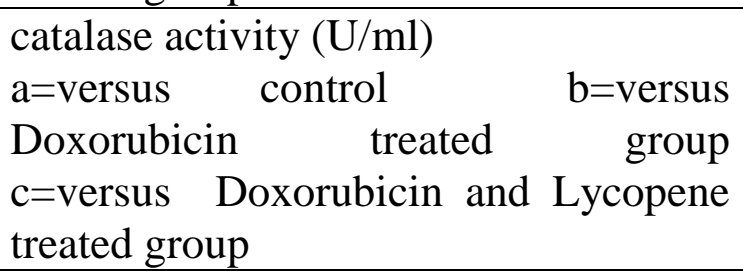 } & \multicolumn{2}{|l|}{$<0.0001 * * a$} & $0.002 * *$ a \\
\hline & \multicolumn{2}{|r|}{0.007} & $0.134 \mathrm{~b}$ \\
\hline & \multicolumn{3}{|c|}{$0.51 \mathrm{c}$} \\
\hline
\end{tabular}

Number of sacrificed rats for each group was 6 rats.
*: significant $(\mathbf{p}<\mathbf{0 . 0 5})$
$* *$ : highly significant $(\mathbf{p}<0.01)$.
NS: non-
significant. 
Table (10): Least significant difference test (LSD) for comparison of the changes of the mean values of SBP, DBP, MBP and HR in-between groups.

\begin{tabular}{|c|c|c|c|c|}
\hline $\mathrm{N}^{-2}$ Group & Control & $\begin{array}{c}\text { Doxorubici } \\
\text { n treated } \\
\text { group }\end{array}$ & $\begin{array}{l}\text { Doxorubicin } \\
\text { and Lycopene } \\
\text { treated group }\end{array}$ & $\begin{array}{l}\text { Doxorubicin } \\
\text { and Saffron } \\
\text { treated group }\end{array}$ \\
\hline \multicolumn{5}{|l|}{ Parameter } \\
\hline \multirow{3}{*}{$\begin{array}{l}\text { SBP } \\
a=\text { versus control b=versus } \\
\text { Doxorubicin treated group } \\
c=\text { ersus Doxorubicin and Lycopene } \\
\text { treated group }\end{array}$} & \multicolumn{2}{|c|}{$<0.0001 * *$ a } & $<0.0001 *$ a & $\begin{array}{c}<0.0001 * * \\
\text { a }\end{array}$ \\
\hline & \multicolumn{3}{|c|}{$<0.0001 * *$ b } & $<0.0001 * * b$ \\
\hline & \multicolumn{4}{|r|}{$0.0002 * *$} \\
\hline \multirow{3}{*}{$\begin{array}{l}\text { DBP } \\
a=\text { ersus control b=versus } \\
\text { Doxorubicin treated group } \\
\mathrm{c}=\text { versus Doxorubicin and Lycopene } \\
\text { treated group }\end{array}$} & $<0.0$ & $01 * *$ & $<0.0001 * *$ a & $0.0018 * *$ a \\
\hline & \multicolumn{3}{|r|}{0.0015} & $\begin{array}{l}<0.0001 * * \\
\text { b }\end{array}$ \\
\hline & \multicolumn{4}{|c|}{$0.0045 * * \mathbf{c}$} \\
\hline \multirow{3}{*}{$\begin{array}{l}\text { MBP } \\
a=\text { versus control b=versus } \\
\text { Doxorubicin treated group } \\
c=\text { versus Doxorubicin and Lycopene } \\
\text { treated group }\end{array}$} & \multicolumn{2}{|c|}{$<0.0001 * * \quad$ a } & $<0.0001 * *$ a & $\begin{array}{c}0.0002 * * \\
\text { a }\end{array}$ \\
\hline & \multicolumn{3}{|c|}{$<0.0001 * *$ b } & $\begin{array}{c}<0.0001 * * \\
\text { b }\end{array}$ \\
\hline & \multicolumn{4}{|c|}{$<0.0001 * * \quad \mathrm{c}$} \\
\hline \multirow{3}{*}{$\begin{array}{l}\text { HR } \\
a=\text { versus control b=versus } \\
\text { Doxorubicin treated group } \\
c=\text { versus Doxorubicin and Lycopene } \\
\text { treated group }\end{array}$} & \multicolumn{2}{|c|}{$<0.0001 * * \quad$ a } & $<0.0001 * *$ a & $0.09 \mathrm{a}$ \\
\hline & \multicolumn{3}{|c|}{$0.001 * * \quad b$} & $\begin{array}{l}<0.0001 * * \\
\text { b }\end{array}$ \\
\hline & \multicolumn{4}{|r|}{$\mathbf{0 . 0 0 8 6}^{* *}$} \\
\hline
\end{tabular}

Number of sacrificed rats for each group was 6 rats.

$*$ : significant $(\mathbf{p}<0.05) \quad * *$ : highly significant $(\mathbf{p}<0.01) . \quad$ NS: non-

significant. 


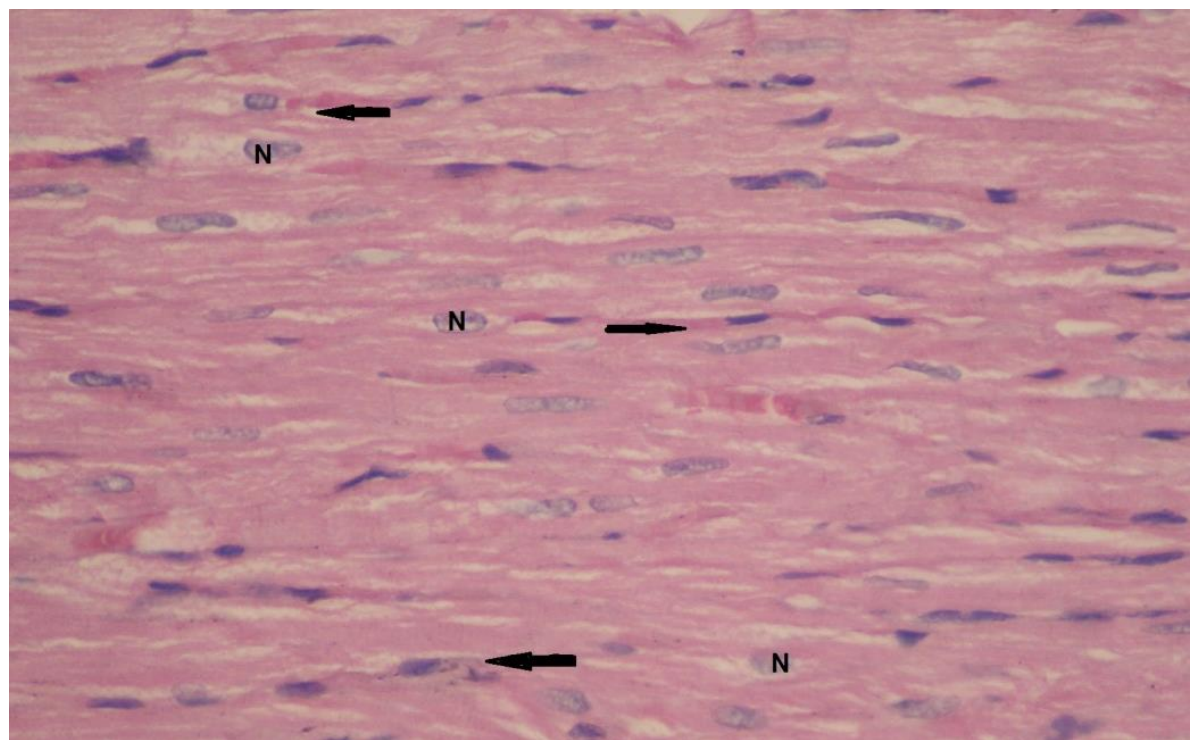

Figure (1): A photomicrograph of a section from heart of the control group showing muscle fibers in different directions that contains acidophilic sarcoplasm (arrow), central pale oval nuclei $(\mathrm{N})$ and delicate connective tissue separating cardiac myocytes. (H \& E X 400).

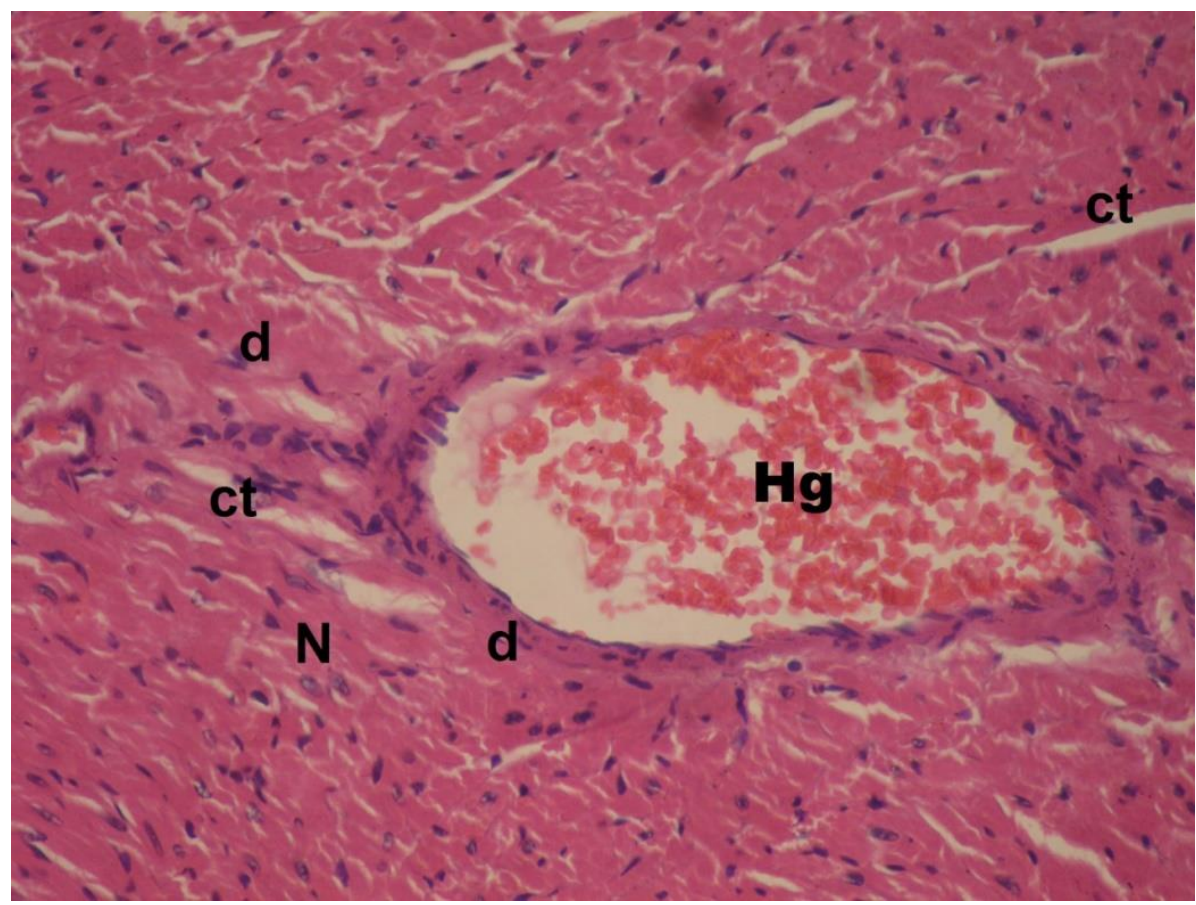

Figure (2): A photomicrograph of a section from the heart of a doxorubicin treated rat showing areas of hemorrage $(\mathrm{Hg})$. Nuclei were either lost or darkly stained $(\mathrm{N})$. Muscle fibers were either separated by wide connective tissue spaces (ct) or appeared degenerated and pale (d). (Hx \& E X 400) 


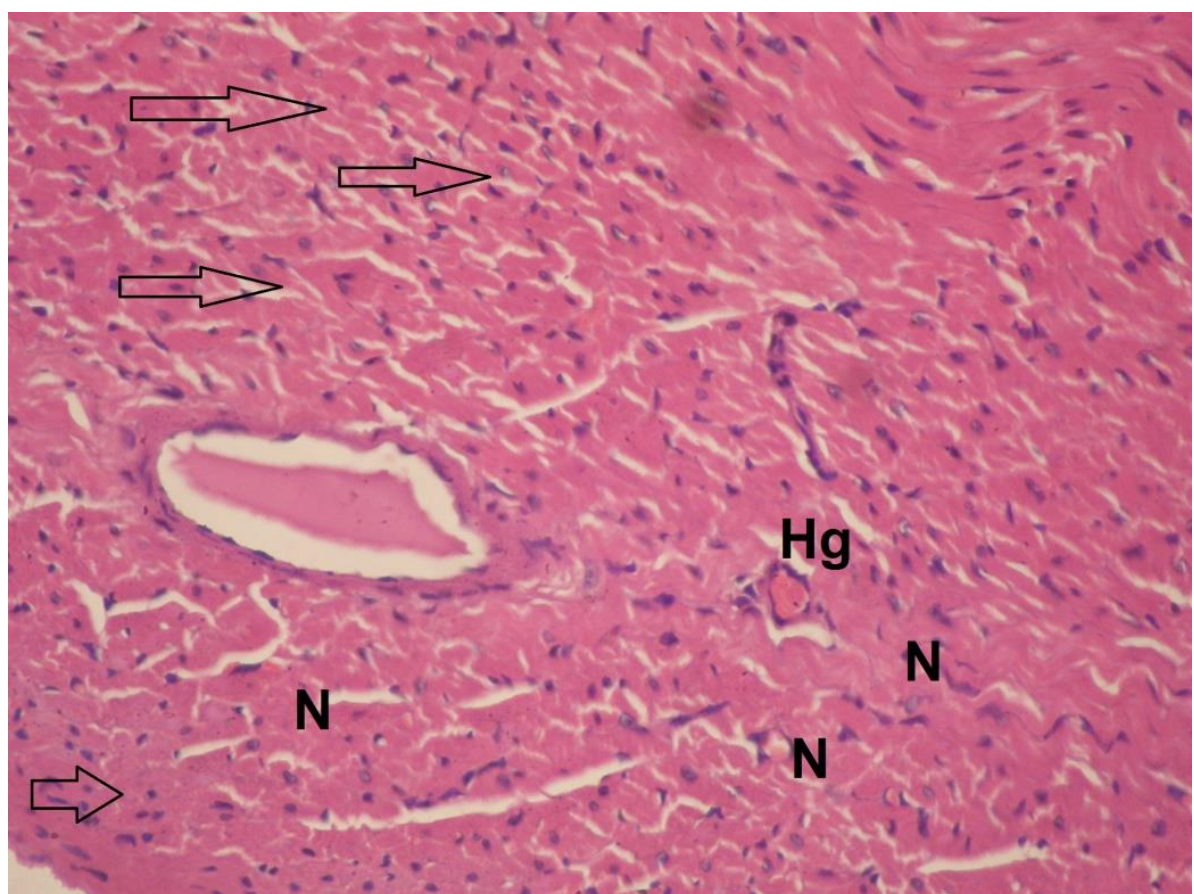

Figure (3): A photomicrograph of a section from heart of a doxorubicin and saffron treated rat showing that some of muscle fibers are normal and contained acidophilic sarcoplasm and central pale oval nuclei $(\mathrm{N})$. Many muscle fibers showing necrosis and their nuclei were lost or darkly stained (arrow) with hemorrhage of heart interstitium (Hg) (H \& E X 400).

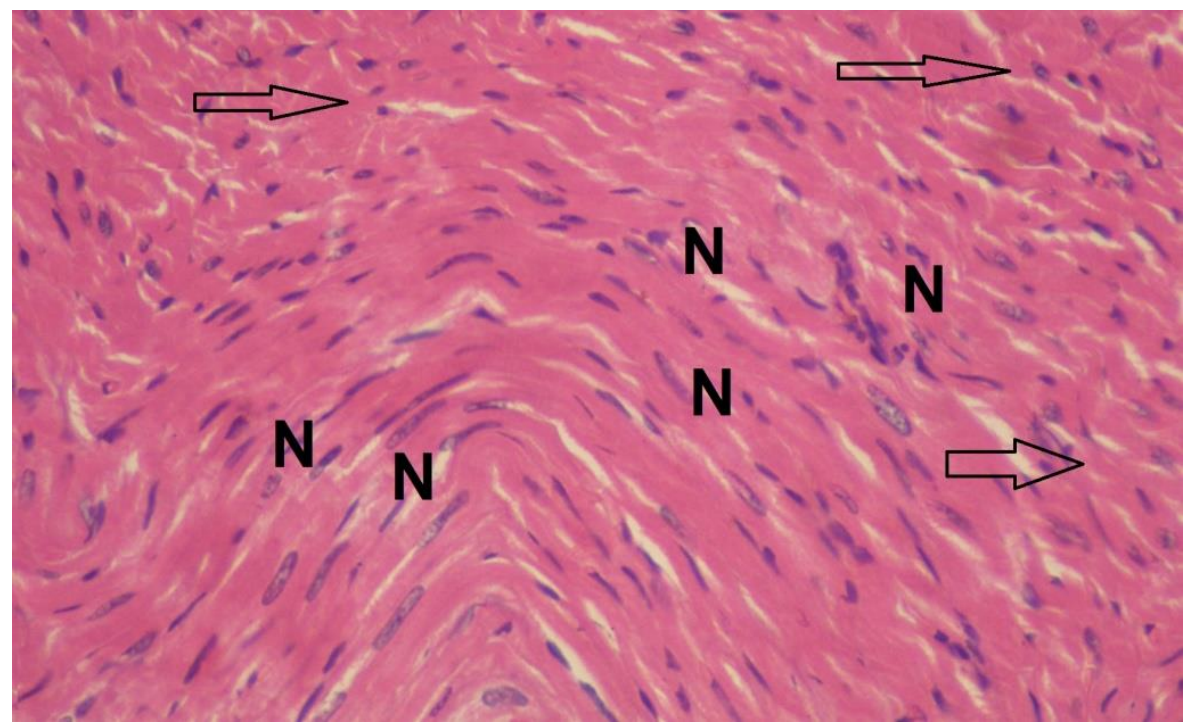

Figure (4): A photomicrograph of a section from heart of a doxorubicin and lycopene treated rat showing that most of muscle fibers are normal and contained acidophilic sarcoplasm and central pale oval nuclei $(\mathrm{N})$.Some muscle fibers showed necrosis and their nuclei were lost or darkly stained (arrow) (H \& E X 400). 


\section{DISCUSSION}

Doxorubicin (DOX) is one of the commonest used antineoplastic drug (Binaschi et al, 2001). Despite its beneficial effects in treating cancer, the clinical use of DOX has a serious limitation due to its cardiotoxic effect (Jones et al., 2006; Simunek et al., 2009). This cardiotoxicity is a common cause of morbidity and premature mortality (Scott et al., 2011). So, strategies to decrease its cardiotoxic side effects are necessary (Dolinsky et al., 2013). Adjuvant therapies that protect the heart tissues without interference with tumor treatment are needed. Such drugs could be beneficial in preventing cardiomyopathy as well as permitting the use of more effective dosages of DOX (Liu et al., 2014).

While research has suggested that the DOX-induced cardiotoxicity is multifactorial (Yi et al., 2006; Scott et al., 2011), many studies support the involvement oxidative stress as a contributing factor (Simunek et al., 2009). So, we aimed to evaluate and compare the possible beneficial effects of lycopene, and saffron as antioxidants against Doxorubicin- induced cardiotoxicity in adult male albino rats.

The present findings indicated that the combined treatment with either lycopene or saffron improved the cardiotoxic effects of doxorubicin in rats. These findings included a decrease of $\mathrm{LDH}$ and CBK-MB in serum, the preservation of heart histopathological morphology, a decrease in oxidative stress markers in cardiac tissue as well as an improvement in blood pressure.

Our findings have confirmed the previous reports that, DOX treatment leads to decreased both body and heart weights in animals ( $\mathbf{L i}$ et al., 2009; Razmaraii et al., 2016c). We found that, lycopene and saffron treatment increased body and heart weights, as compared to DOX treated group.

Doxorubicin (DOX)- induced heart toxicity is characterized by free radicals' generation in the heart (Gao et al., 2015; El-Sayed et al. 2016). The present study proved that the activity of SOD and CAT were significantly decreased in the DOX group and the co-treatment with either lycopene or saffron increased SOD and CAT activity. MDA is a marker for lipid peroxidation (Torun et al., 2009). In the present study, blood levels of MDA were markedly increased in the DOX group, and this was significantly reversed in antioxidants treated groups.

The protective effects of saffron and its antioxidant effect have been shown against many chemical-induced cardiovascular toxicity as Diazinon (Razavi et al., 2013), and isoproterenol (Goyal et al., 2010). In line with our study, Chahine et al (2016) mentioned that, SAF has antioxidant therapeutic effect against DOX cardiotoxicity.

Yilmaz et al. (2006) mentioned the protective role of lycopene in DOXinduced cardio and nephro toxicities using both biochemical and histopathological assessments and explained the role of lycopene in inhibiting lipid peroxidation and improve antioxidant parameters in both heart and kidneys.

This study showed significant deterioration of cardiac function in the DOX-treated rat group compared to the control group. A number of parameters were investigated to assess cardiac damage after DOX treatment. Heart rate has been considered as an independent risk factor in cardiovascular disease (Cooney et al., 2010). This study showed a significant 
decrease in the heart rate in the DOXtreated group. Also, DOX caused a decrease in the systolic, diastolic, mean BP. These results were in line with previous results of (Ozdoğan et al., 2011; Momin et al., 2012; Ammar et al. 2015). This hemodynamic disturbance caused by DOX could be attributed to disruption of the myofibrils (Weinberg and Singal, 1987; Momin et al., 2012).

When saffron was admitted as a cotreatment it was able to prevent the development of DOX induced hemodynamic disturbance which was consistent with Sachdeva et al. (2012) who reported that saffron treatment for 4 weeks improved systolic, diastolic, and mean arterial pressure in rat myocardium exposed to large doses of isoproterenol. Also, another study was stated that, Crocin $(20 \mathrm{mg} / \mathrm{kg}$, IP, for 28 days) improved toxic effects of diazinon by decreasing lipid peroxidation and restoring disturbed contractile and relaxant responses in rat aorta. Also, concurrent administration of crocin and diazinon could restore the effects of subchronic diazinon administration on both systolic blood pressure and heart rate in rats (Razavi et al., 2013; 2014).

The improvement in cardiac function may come from the antiarrhythmic effect of saffron and the preventive loss of contractile proteins (Troponin $\mathrm{C}$ and $\alpha$-actinin). Also, saffron scavenges ROS in the affected myocardium leading to less damage in cells and preservation of contractile proteins (Nader et al., 2016).

Regarding cardiac function in combined DOX-lycopene treated group, there was significant increase in the systolic, diastolic, mean BP, heart rate in combined DOX \&lycopene treated group when compared to DOX treated group. This protective effect of lycopene on DOX-induced hemodynamic instability came in agreement with Aman et al., (2012), who found that supplementation of LYP significantly attenuated the hemodynamic changes occur in myocardium exposed to toxic doses of isoproterenol.

The serum LDH and CPK-MB enzyme activities are considered as important measures in early and late phases of cardiac injury. These enzymes are released from the heart into the blood during myocardial damage due to deficiency of oxygen or glucose, the cell membrane become permeable or may rupture and results in the leakage of it in the serum (Arya et al., 2006). This study stated that, serum $\mathrm{LDH}$ and CPK-MB were increased after Dox administration in rats. These results are in good agreement with findings of (Koti et al., 2009; Swamy, et al., 2012).

Both CPK-MB and LDH are not specific for myocardial injury individually; however, evaluation of these two enzymes together may be an indicator of myocardial injury (Swamy, et al., 2012).

Regarding serum LDH and CPKMB enzyme in antioxidant treated groups, there was highly significant difference in combined DOX and LYC when compared to DOX treated group, while there was significant difference in combined DOX and SAF in comparison to DOX only treated group. The potential protective effects of LYC and SAF against cardiac enzymes changes in the present study were consistent with previous work of Lin et al., (2016) and Mehdizadeh et al. (2013) respectively. 
Cardiac troponin is a complex of three regulatory proteins (troponin $\mathrm{C}, \mathrm{I}$, and $\mathrm{T}$ ), attached to the actin filament in skeletal or cardiac muscle tissue, and is important for muscle contraction. Its levels are used as a diagnostic marker for diffrent heart disorders including DOX-induced crdiotoxicity (Mahajan and Jarolim, 2011). Increased level of cardiac troponin in the DOX-treated rats of this study was in line with several studies (Thompson $\mathbf{K}$ et al., 2010; Lipshultz et al., 2012; Desai et al., 2013).

Cardiac troponin I levels were highly significantly decreased in the DOX-lycopene treated rats when compared to DOX-treated rat group, and significantly decreased in DOXsaffron when compared to DOX-treated rat group.

Previous reports have documented that saffron consumption could prevent cardiac toxicity and decreased serum levels of cardiac troponin I in rats with isoproterenol induced myocardial toxicity (Joukar et al., 2010), and that lycopene, given in a dose of $4 \mathrm{mg} / \mathrm{kg}$, orally once daily for 21 days, could improve cardiac lesion parameters, including cardiac troponin in isoproterenol-induced cardiotoxicity (Mohamadin et al., 2012).

In the present study, rats of the control group did not show any histopathological changes and heart showed normal appearance (fig.1).

On the contrary, various histopathological changes such as interstitial edema, focal myocardial fibrosis, perinuclear vacuolation and myocardial necrosis were observed following DOX treatment (fig.2). These result was reported in different experimental animal studies (Yilmaz et al., 2006; Dogan et al., 2010;
Razmaraii et al., 2016 a, c).

Treatment with either saffron or lycopene demonstrated less disruption of the myofibrils and less vacoulization of the cytoplasm (fig.3, 4).

In line with the present study, Karimi et al. (2005) who stated that doxorubicin induced histopathological changes in cardiac tissues which prevented by lycopene treatment.

Also, Yilmaz et al., (2006) found similar results.

According to Joukar et al. (2010) saffron adminstration decrease histopathological cardiac lesions in rats exposed to isoproterenol induced myocardial toxicity.

Razmaraii et al., (2016 B) showed that saffron treatment significantly improved DOX-induced structural changes in the myocardium.

Many studies try to identify the mechanism of DOX induced cardiotoxicity (Singal et al 1997; Minotti et al., 2004; Razmaraii et al., 2016 c), but no single explanation was able to clarify the cause of it (Tokarska-Schlattner et al., 2006).

The most important cause of DOX related cardiotoxicity was attributed to oxidative stress. So, antioxidants can be protective against this by free radical scavenging ability (Horenstein et al., 2000; Ferreira AL et al., 2008).

Currently, dexrazoxane, is the only antioxidant drug approved by the US Food and Drug Administration for clinical use with Doxo to decrease its cardiotoxicity. Despite that, its administration is limited due to the controversial results linking its use with the risk of secondary malignancies (Tebbi et al., 2007). So, searching for other beneficial antioxidants is mandatory.

Many studies have been proved that 
lycopene has powerful antioxidant activity both in vitro and in vivo 100 times more efficiently than vitamin $\mathrm{E}$ and 125 times more than glutathione (Stahl and Sies, 2007; Mein et al., 2008).

Saffron high antioxidant capacity was investigated by many studies (Ochiai et al., 2004; Magesh et al. 2006; Kanakis et al. 2007; Soeda et al. 2007; Tavakkol-Afshari et al. 2008; Asdaq and Inamdar 2010; Bathaie and Mousavi 2010; Karimi et al. 2010; Makhlouf et al. 2011). Several mechanisms explain the protective effects of saffron against cardiotoxicty induced by many chemical, including modulation of cardiac hemodynamic

histopathological and ultrastructural impairments (Goyal et al., 2010), improvement in cardiac markers such as CK-MB(Razavi et al., 2013), and (Mehdizadeh et al., 2013), and alleviation of lipid peroxidation (Razavi et al., 2013).

\section{CONCLUSION}

Both SAF and LYC have beneficial effects against doxorubicin inducedcardiotoxicity due to their potent antioxidant effects, with the advantage to LYC over SAF. The advantage of LYC over SAF in the current study may be due its observed cardioprotective effects.

\section{RECOMMENDATION:}

As the findings in the current study have not yet been verified by clinical investigations, so, human trials should be carried out, to establish the potential protective effects of lycopene and saffron in human intoxications. Future experiments are required to evaluate the possible protective molecular mechanisms of lycopene and saffron against DOX-induced cardiotoxicity. Further animal investigations to examine the possible beneficial effects of combined treatment of lycopene and saffron against DOX-induced cardiotoxicity, are necessary.

\section{REFERENCES}

Aebi, H. (1983): Catalase. In: Methods in enzymatic analysis, Bergmeyer HU (ed.), volume 3. Academic Press, New York, PP. 276-286.

Aman, U.; Vaibhav, P. and Balaraman, R. (2012): Tomato lycopene attenuates myocardial infarction induced by isoproterenol:Electrocardiograpi, biochemical and anti-apoptotic study. Asian Pac. J. Trop. Biomed., 2(5): 345-351.

Ammar, H.I.; Sequiera, G.L.; Nashed, M.B.; Ammar, R.I.; Gabr, H.M.; Elsayed, H.E.; Sareen, N.; Abu-El Rub, E.; Zickri, M.B. and Dhingra, S. (2015): Comparison of adipose tissue- and bone marrow- derived mesenchymal stem cells for alleviating doxorubicin-induced cardiac dysfunction in diabetic rats. Stem Cell Res. Ther., 6(1): 148.

Arya, D.S.; Bansal, P.; Ojha, S.K.; Nandave, M.; Mohanty, I. and Gupta, S.K. (2006): Pyruvate provides cardioprotection in the experimental model of myocardial ischemia reperfusion injury. Life Sci., 79:38-4

Asdaq, S.M.B. and Inamdar, M.N. (2010): Potential of Crocus sativus (saffron) and its constituent, crocin, as hypolipidemic and antioxidant in rats. Appl. Biochem. Biotechnol., 162:358-372.

Assimopoulou, A.N.; Sinakos, Z. and 
Papageorgiou, V.P. (2005):

Radical scavenging activity of Crocus sativus L. extract and its bioactive constituents. Phytother Res., 19(11):997-1000.

Bathaie, S.Z. and Mousavi, S.Z. (2010): New applications and mechanisms of action of saffron and its important ingredients. Crit. Rev. Food Sci. Nutr., 50(8):761768.

Beutler, E.; Duron, O. and Kelly, M.B. (1963): Improved method for the determination of blood glutathione. J. Lab. Clin. Med., 61: 882-888.

Binaschi, M. (2001): Anthracyclines: selected new developments. Current medicinal chemistry. Curr Med Chem Anticancer Agents, 1(2):113-130.

Bramley, P.M. (2000): Is lycopene beneficial to human health? Phytochemistry, 54(3):233-236.

Buhl, S. N. and Jackson, K.Y. (1978): Optimal conditions and comparison of lactate dehydrogenase catalysis of the lactate-to-pyruvate and pyruvate-to-lactate reactions in human serum at 25, 30, and 37 degrees

C. ClinicalChemistry, 24(5):828831.

Bunag, M.A.; Rubend, D. and Jason Butterfield, B.S. (1982): Tail Cuff BP Measurement without external preheating in awake rats. Hypertension, 4: 898-902.

Chahine, N.; Nader, M.; Duca, L.; Martiny, L. and Chahine, R. (2016): Saffron extracts alleviate cardiomyocytes injury induced by doxorubicin and ischemiareperfusion in vitro. Drug Chem. Toxicol., 39(1):87-96.

Collinson, P.O.; Boa, F.G. and Gaze,
D.C. (2001): Measurement of cardiac troponins. Ann. Clin. Biochem., 38:423-9.

Cooney, M.T.; Vartiainen, E.; Laatikainen, T.; Juolevi, A.; Dudina, A. and Graham, I.M. (2010): Elevated resting heart rate is an independent risk factor for cardiovascular disease in healthy men and women. Am. Heart J., 159:612-9.

Corna, G.; Santambrogio, P.; Minotti, G. and Cairo, G. (2004): Doxorubicin paradoxically protects cardiomyocytes against ironmediated toxicity: role of reactive oxygen species and ferritin. The Journal of biological chemistry, 279(14):13738-13745.

Datta, S.; Jamwal, S.; Deshmukh, R. and Kumar, P. (2016): Beneficial effects of lycopene against haloperidol induced orofacial dyskinesia in rats: Possible neurotransmitters and neuroinflammation modulation. Eur. J. Pharmacol., 771:229-235.

Desai, V.G.; Herman, E.H.; Moland, C.L.; Branham, W.S.; Lewis, S.M.; Davis, K.J.; George, N.I.; Lee, T.; Kerr, S. and Fuscoe, J.C. (2013): Development of doxorubicin-induced chronic cardiotoxicity in the B6C3F1 mouse model. Toxicol. Appl. Pharmacol., 266:109-121.

Dogan, I.; Sonmez, B.; Turker. O.; Yenilmez, E.; Uçar. U. and Zengin, A. (2010): Decreased myocardial Tl-201 uptake in rats: Early sign of doxorubicin induced myocardial damage and the relation to inflammation. Eur. J. Gen. Med., 7(1):43-49.

Dolinsky, V.W.; Rogan, J.; Sung, M.; Zordoky, N.; Haykowsky, 
J.; Young, E.; Jones,W.; Jason R. B. and Dyck, R.B. (2013): Both aerobic exercise and resveratrol supplementation attenuate doxorubicin-induced cardiac injury in mice. Am J Physiol Endocrinol Metab., 15; 305(2): 243-253.

Doroshow, J. H.; Locker, G. Y. and Myers, C. E.(1980): Enzymatic defenses of the mouse heart against reactive oxygen metabolites. Alterations produced by doxorubicin. The Journal of Clinical Investigation, 65(1):128135

El-Sayed, E.M.; Mansour, A.M. and Abdul-Hameed, M.S. (2016): Thymol and carvacrol prevent doxorubicin-induced cardiotoxicity by abrogation of oxidative stress, inflammation, and apoptosis in rats. J. Biochem. Mol. Toxicol. , 30:3744.

Fernández, J.A. (2006): Anticancer properties of saffron, Crocus sativus Linn. In: Mahmud THK, Arjumand A, editors. Advances in Phytomedicine. Netherlands: Elsevier, pp. 313-30.

Ferreira, A.L.; Matsubara, L.S. and Matsubara, B.B. (2008): Anthracycline-induced cardiotoxicity. Cardiovasc. Hematol. Agents Med. Chem., 6(4):278-81.

Gao, Y.; Xu, Y.; Hua, S.; Zhou, S. and Wang, K. (2015): ALDH2 attenuates Dox-induced cardiotoxicity by inhibiting cardiac apoptosis and oxidative stress. Int. J. Clin. Exp. Med., 8:6794-6803.

Goyal, S.N.; Arora, S., Sharma, A.K.; Joshi ,S.; Ray, R.; Bhatia, J.; Kumari, S. and Arya, D.S.(2010):Preventive effect of crocin of crocus sativus on hemodynamic, biochemical, histopathological and ultrastructure alterations in isoproterenolinduced cardiotoxicity in rats.phytomedicine, 17:227-232.

Horenstein, M.S.; Vander, H.R.S. and L'Ecuyer, T.J. (2000): Molecular basis of anthracyclineinduced cardiotoxicity and its prevention. Mol. Genet. Metab., 71(1-2):436-44.

Horobin, R.W. and Bancroft, J.D. (1998): Hematoxylin and eosin as an oversight stain. In: Trubleshooting Histology stains, $1^{\text {st }}$ ed., Churchill Livingstone Press, San Francisco, pp. 88-93.

Hosseinzadeh, $H$. and Ziaei, T. (2006): Effects of Crocus sativus stigma extract and its constituents, crocin and safranal, on intact memory and scopolamine-induced learning deficits in rats performing the Morris water maze task. J. Med. Plant, 5:40-8.

Ichikawa, Y.; Ghanefar, M.; Bayeva, M.; Wu, R.; Khechaduri, A. and Naga Prasad S.V. (2014): Cardiotoxicity of doxorubicin is mediated through mitochondrial iron accumulation. The Journal of clinical investigation, 124(2):617630.

Johnson, E.J. (2002): The role of carotenoids in human health. Nutr Clin Care, 5:56-65.

Jones, R.L.; Swanton, C. and Ewer, M.S. (2006): Anthracycline cardiotoxicity. Expert Opin. Drug Saf., 5(6):791-809.

Joukar, S.; Najafipour, H.; Khaksari, M.; Sepehri, G.; Shahrokhi, N. and Dabiri, S. (2010): The effect of saffron consumption on biochemical and histopathological heart indices of rats with 
myocardial infarction. Cardiovasc.

Toxicol., 10:66-71.

Kanakis, C.D.; Tarantilis, P.A.; Taimir-Riahi, H. and Polissiou, M.G. (2007): Crocetin, dimethylcrocetin, and safranal bind human serum albumin: stability and antioxidative properties. J. Agric. Food Chem., 55:970-977.

Karimi, E.; Oskoueian, E.; Hendra, R. and Jaafar, H.Z.E. (2010): Evaluation of Crocus sativus L. stigma phenolic and flavonoid compounds and its antioxidant activity. Molecules, 15:6244-6256.

Karimi, G.; Ramezani, M. and Abdi, A. (2005): Protective effects of lycopene and tomato extract against doxorubicin-induced cardiotoxicity. Phytotherapy

Research, 19(10):912-914.

Koti, B.C.; Vishwanathswamy, A.H.; Wagawade J. and Thippeswamy AH (2009): Cardioprotective effect of lipistat against doxorubicin induced myocardial toxicity in albino rats. Indian J. Exp. Biol., 47:41-46

Kumar, P.; Kalonia, H. and Kumar, A. (2009): Lycopene modulates nitric oxide pathways against 3nitropropionic acid-induced neurotoxicity. Life Sci., 85:711718.

Li, J.; Liu, H. and Ramachandran S. (2010): Grape seed proanthocyanidins ameliorate doxorubicin-induced cardiotoxicity. American Journal of Chinese Medicine, 38(3):569-584.

Li, W.; Xu, B.; Xu, J. and Wu, X.L. (2009): Procyanidins produce significant attenuation of doxorubicin-induced cardiotoxicity via suppression of oxidative stress. Basic Clin. Pharmacol. Toxicol.,
104(3):192-7.

Lin, J.; Li, H.; Xia, J.; Li, X.; Jiang, X.; Zhu, S.; Ge, J. and Li, J. (2016): The chemopreventive potential of lycopene against atrazine-induced cardiotoxicity: modulation of ionic homeostasis. Sci. Rep., 6: 24855.

Lipshultz, S.E.; Cochran, T.R.; Franco, V.I. and Miller, T.L. (2013): Treatment-related cardiotoxicity in survivors of childhood cancer. Nature reviews Clinical oncology, 10:697-710.

Lipshultz, S.E.; Miller, T.L.; Scully, R.E.; Lipsitz, S.R.; Rifai, N.; Silverman, L.B.; Colan, S.D.; Neuberg, D.S.; Dahlberg, S.E.; Henkel, J.M. and Asselin, B.L. (2012): Changes in Cardiac Biomarkers During Doxorubicin Treatment of Pediatric Patients With High-Risk Acute Lymphoblastic Leukemia: Associations With Long-Term Echocardiographic Outcomes. J. Clin. Oncol. 20:12-16.

Liu,Y.; Asnani,A.; Zou,L.; Bentley, L.; Yu, M;. Wang, Y.; Dellaire, G.; Sarkar, S.; Dai, M. and Chen, H. (2014): Visnagin protects against doxorubicin-induced cardiomyopathy through modulation of mitochondrial malate dehydrogenase. Sci. Transl. Med., 6(266): 170-266.

Luo, C. and Wu, X.G. (2011): Lycopene enhances antioxidant enzyme activities and immunity function in N-Methyl-N'-nitro-Nnitrosoguanidine-induced gastric cancer rats. Int. J. Mol. Sci., 12: 3340-3351.

Magesh, V.; Singh, J.P.V.; Selvendiran, K.; Ekambaram, G. and Sakthisekaran, D. (2006): 
Antitumor activity of crocetin in accordance to tumor incidence, antioxidant status, drug methabolizing enzymes and histopathological studies. Mol. Cell Biochem., 287:127-135.

Mahajan, V.S. and Jarolim, P. (2011): How to interpret elevated cardiac troponin levels. Circulation, 124:2350-2354.

Maiani, G.; Castón, M.J.; Catasta, G.; Toti, E.; Cambrodón, I.G.; Bysted, A.; Granado-Lorencio, F.; Olmedilla-Alonso, B.; Knuthsen, P. and Valoti, $M$. (2009): Carotenoids: actual knowledge on food sources, intakes, stability and bioavailability and their protective role in humans. Mol. Nutr. Food Res., 53 (2): 194218.

Makhlouf, H.; Saksouk, M.; Habib, J. and Chahine, R. (2011): Determination of antioxidant activity of saffron taken from the flower of Crocus sativus grown in Lebanon. Afr. J. Biotechnol., 10(41):8093-8100.

Mehdizadeh, R.; Parizadeh, M.R.; Khooei, A.R.; Mehri, S. and Hosseinzadeh, H. (2013): Cardioprotective effect of saffron extract and safranal in isoproterenol-induced myocardial infarction in wistar rats. Iran J. Basic Med. Sci., 16:56-63.

Mein, J.R.; Lian, F. and Wang, X.D. (2008): Biological activity of lycopene metabolites: implications for cancer prevention. Nutr Rev., 66:667-683.

Minotti, G.; Menna, P.; Salvatorelli, E.; Cairo, G. and Gianni, L. (2004): Anthracyclines: molecular advances and pharmacologic developments in antitumor activity and cardiotoxicity. Pharmacol. Rev., 56(2):185-229.

Mohamad, R.H.; El-Bastawesy, A.M. and Zekry, Z.K. (2009): The role of Curcuma longa against doxorubicin (Adriamycin)-induced toxicity in rats. Journal of Medicinal Food, 12(2):394-402.

Mohamadin, A.M.; Elberry, A.A.; Mariee, A.D.; Morsy, G.M. and Al-Abbasi, F.A.(2012): Lycopene attenuates oxidative stress and heart lysosomal damage in isoproterenol induced cardiotoxicity in rats: A biochemical

Pathophysiology, 19(2):121-130.

Momin, F.M.; Kalai,B.R.; Shikalgar, T.S. and Naikwade, N.S. (2012): Cardioprotective effect of methanolic extract of Ixora coccinea Linn. leaves on doxorubicin-induced cardiac toxicity in rats. Indian $\mathrm{J}$. Pharmacol., 44(2): 178-183.

Nader, M.; Chahine, N.; Salem, C. and Chahin, R. (2016): Saffron (Crocus sativus) pretreatment confers cardioprotection against ischemia-reperfusion injuries in isolated rabbit heart. J. Physiol. Biochem.,72: 711-719

NIBP 250 User's Guide (2013): Noninvasive Blood Pressure Measurement System. Available at www.biopac.com.

Ochiai, T.; Ohno, S.H.; Soedo, S.H.; Tanaka, H.; Shoyama, Y. and Shimeno, H. (2004): Crocin prevents the death of rat pheochromyctoma (PC-12) cells by its antioxidant effect stonger than those of $\alpha$-tocopherol. Neurosci Lett., 362:61-64.

Octavia, Y.; Tocchetti, C.G.; Gabrielson, K.L.; Janssens, S.; Crijns, H.J. and Moens A.L. 
(2012): Doxorubicin-induced cardiomyopathy: From molecular mechanisms to therapeutic strategies. J. Mol. Cell Cardiol., 52(6):1213-1225

Ohkawa, H.; Ohishi, N. and Yagi, K. (1979): Assay for lipid peroxides in animal tissues by thiobarbituric acid reaction. Anal. Biochem., 95: 351-358.

Ozdoğan, K.; Taşkın, E. and Dursun, N. (2011): Protective effect of carnosine on adriamycin-induced oxidative heart damage in rats. Anadolu Kardiyol Derg., 11:3-10.

Papandreou, M.A.; Kanakis, C.D.; Polissiou, M.G.; Efthimiopoulos, S.; Cordopatis, P. and Margarity, M. (2006): Inhibitory activity on amyloid-beta aggregation and antioxidant properties of Crocus sativus stigmas extract and its crocin constituents. J. Agric. Food Chem., 54:8762-8.

Razavi, M.; Hosseinzadeh, H.; Abnous, K.; Motamedshariaty, V. and Imenshahidi, M. (2013): Crocin restores hypotensive effect of subchronic administration of diazinon in rats. Iran $\mathbf{J}$ Basic Med Sci., 16:64-72.

Razavi, B.; Hosseinzadeh, H.; Abnous, K. and Imenshahidi, $M$. (2014): Protective effect of crocin on diazinon induced vascular toxicity in subchronic exposure in rat aorta ex-vivo. Drug Chem. Toxicol., 37:378-830.

Razmaraii, N.; Babaei, H.; Nayebi, A.M.; Assadnassab, G.; Helan, J.A. and Azarmi, Y.(2016a):Cardioprotective effect of phenytoin on doxorubicininduced cardiac toxicity in a rat model. J Cardiovasc Pharmacol., 67(3):237-45.
Razmaraii, N.; Babaei, H.; Nayebi, A.M.; Assadnassab, G.; Helan, J.A. and Azarmi, Y.(2016b): Crocin treatment prevents doxorubicin-induced cardiotoxicity in rats. Life Sci., 15; 157:145-51.

Razmaraii, N.; Babaei, H.; Nayebi, A.M.; Assadnassab, G.; Helan, J.A. and Azarmi, Y.(2016c):Cardioprotective Effect of Grape Seed Extract on Chronic Doxorubicin-Induced Cardiac Toxicity in Wistar Rats. Adv. Pharm. Bull., 6(3): 423-433.

Ried, K. and Fakler, P. (2011): Protective effect of lycopene on serum cholesterol and blood pressure: Meta-analyses of intervention trials. Maturitas., 68:299-310.

Sachdeva, A.K. and Chopra, K. (2015): Lycopene abrogates $A \beta(1-$ 42)-mediated neuroinflammatory cascade in an experimental model of Alzheimer's disease. J. Nutr. Biochem., 26:736-744.

Sachdeva, J.; Tanwar, V.; Golechha, M.; Siddiqui, K.M.; Nag, T.C; Ray, R.; Kumari, S. and Arya, D.S. (2012): Crocus sativus L. (saffron) attenuates isoproterenolinduced myocardial injury via preserving cardiac functions and strengthening antioxidant defense system. Exp. Toxicol. Pathol., 64(6):557-564.

Scott, J.M.; Khakoo, A.; Mackey, J.R.; Haykowsky, M.J.; Douglas, P.S. and Jones, L.W. (2011): Modulation of anthracyclineinduced cardiotoxicity by aerobic exercise in breast cancer: current evidence and underlying mechanisms. Circulation, 124: 642-650.

Semler, D.E. (1992): The rat 
toxicology. In: animal models in toxicology, by Gad, S.C. and Chengelis, C.P., Marcl Dekker Inc. New York, pp 21- 75.

Shen, X.C. and Qian, Z.Y. (2006): Effects of crocetin on antioxidant enzymatic activities in cardiac hypertrophy induced by norepinephrine in rats. Pharmazie, 61(4):348-52.

Shi, Y.; Moon, M.; Dawood, S.; McManus, B. and Liu, P.P. (2011): Mechanisms and management of doxorubicin cardiotoxicity. Herz, 36(4):296305.

Simunek, T.; Sterba, M.; Popelova, O.; Adamcova, M.; Hrdina, R.and Gersl, V. (2009): Anthracycline-induced cardiotoxicity: overview of studies examining the roles of oxidative stress and free cellular iron. Pharmacol Rep., 61(1):154-171.

Singal, P.K.; Iliskovic, N.; Li, T. and Kumar, D. (1997): Adriamycin cardiomyopathy: pathophysiology and prevention. FASEB J., 11(12):931-936.

Soeda, S.H.; Ochiai, T.; Shimeno, H.; Saito, H.; Abe, K.; Tanaka, H. and Shoyama, Y. (2007): Pharmacological activities of crocin in saffron. J. Nat. Med., 61:102111.

SPSS Inc (2013): SPSS for windows, version 22.0. Chicago, SPSS Inc. http://www.unimunester.de/impe ria/md/content/ziv/service/softwa r

e/spss/handbuecher/englisch/spss _brief_guide_22.0.pdf.

Stacewicz-Sapuntzakis, M. and Bowen, P.E. (2005): Role of lycopene and tomato products in prostate health. Biochim. Biophys.
Acta, 1740: 202-205.

Stahl, W. and Sies, H. (2007): Carotenoids and flavonoids contribute to nutritional protection against skin damage from sunlight. Mol. Biotechnol., 37:26-30.

Swamy, A.V.; Gulliaya, S.; Thippeswamy, A.; Koti, B.C. and Manjula, D.V.(2012): Cardioprotective effect of curcumin against doxorubicin-induced myocardial toxicity in albino rats. Indian J. Pharmacol., 44(1): 73-77.

Tavakkol-Afshari, J.; Brook, A. and Mousavi, S.H. (2008): Study of cytotoxic and apoptogenic properties of saffron extract in human cancer cell lines. Food Chem. Toxicol., 46:3443-3447.

Tebbi, C.K.; London, W.B. and Friedman, D. (2007): Dexrazoxane-associated risk for acute myeloid leukemia/myelodysplastic syndrome and other secondary malignancies in pediatric Hodgkin's disease. J. Clin. Oncol., 25:493-500

Thompson, K.; Rosenzweig, B.; Zhang, J.; Knapton, A.; Honchel, R.; Lipshultz, S.; Retief, J.; Sistare, F and Herman, E.(2010): Early alterations in heart gene expression profiles associated with doxorubicin cardiotoxicity in rats. Cancer Chemother. Pharmacol., 66:303-314.

Tokarska-Schlattner, M.; Zaugg, M.; Zuppinger, C.; Wallimann, T. and Schlattner, U. (2006): New insights into doxorubicin-induced cardiotoxicity: The critical role of cellular energetics. J. Mol. Cell Cardiol. ,41(3):389-405.

Torun, A.N.; Kulaksizoglu, S.; Kulaksizoglu, M.; Pamuk, B.O.; 
Isbilen, E. and Tutuncu, N.B.(2009): Serum total antioxidant status and lipid peroxidation marker malondialdehyde levels in overt and subclinical hypothyroidism. Clin. Endocrinol. (Oxf), 70:469474.

Weinberg, L.E. and Singal, P.K. (1987): Refractory heart failure and age-related deferences in adriamycin-induced myocardial changes in rats. Can J Physiol Pharmacol., 65:1957-1965.

Wu, A. H. B.and Bowers, G. N., Jr. (1982): Evaluation and comparison of immunoinhibition and immunoprecipitation methods for differentiating $\mathrm{MB}$ and $\mathrm{BB}$ from macro forms of creatine kinase isoenzymes in patients and healthy individuals. Clinical Chemistry, 28(10):2017-2021.

Yi, X.; Bekeredjian, R.; DeFilippis, N.J.; Siddiquee, Z.; Fernandez, E. and Shohet, R.V.(2006): Transcriptional analysis of doxorubicin-induced cardiotoxicity. Am. J. Physiol. Heart Circ. Physiol., 290: 1098-1102.

Yilmaz, S.; Atessahin, A.; Sahna, E.; Karahan, I.and Ozer, S. (2006): Protective effect of lycopene on adriamycin-induced cardiotoxicity and nephrotoxicity. Toxicology, 218(2-3):164-171. 


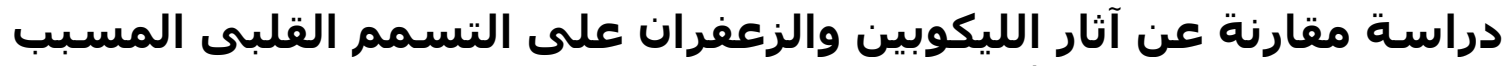

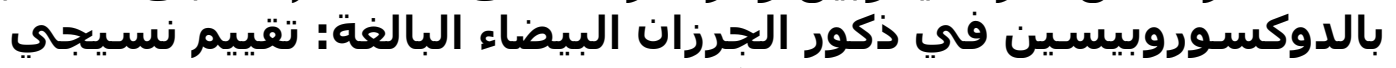
وبيوكيميائي الجيض

\author{
نشوى محمد محمد شلبى, وفاء ابر اهيم سليمان

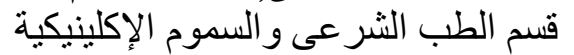 \\ كليه الطب البشرى- جامعة الزقازيق
}

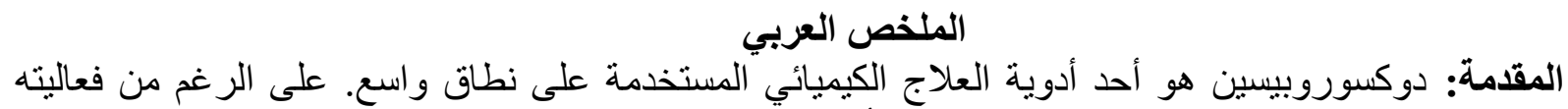

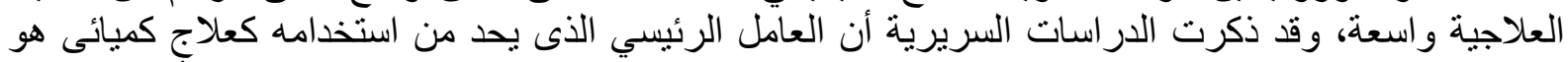

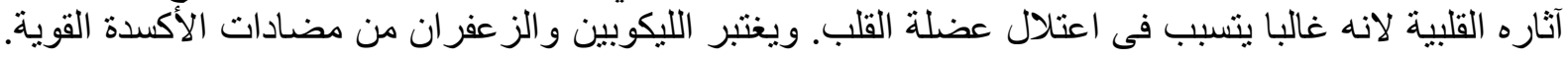

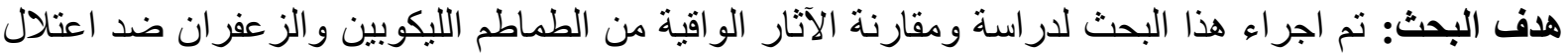

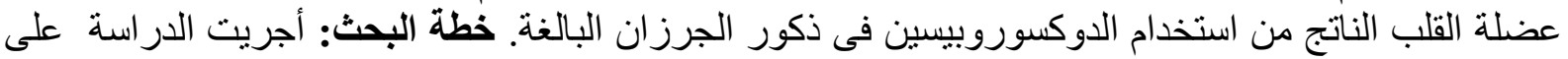

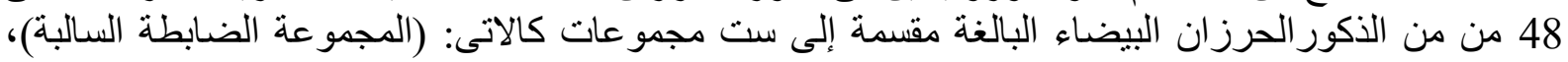

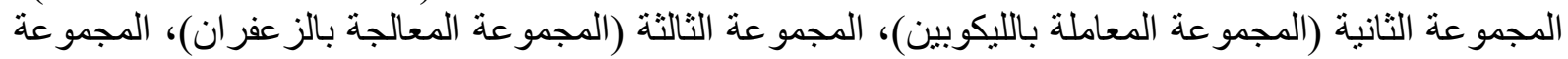

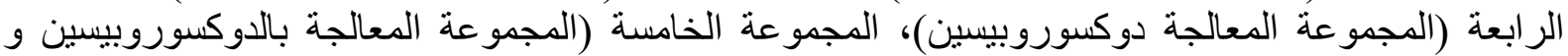

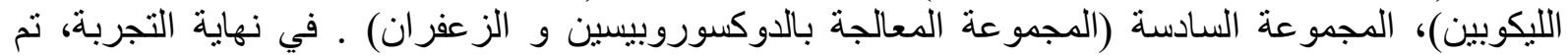

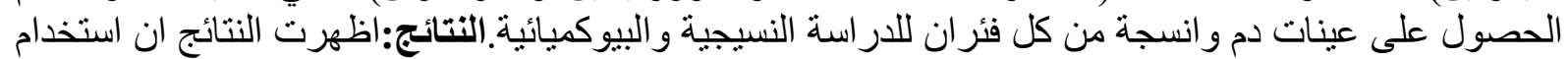

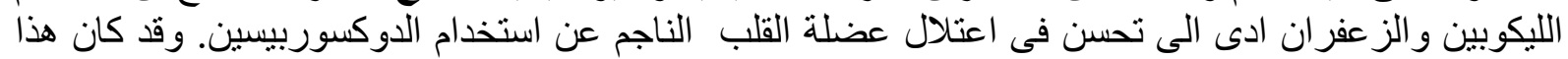

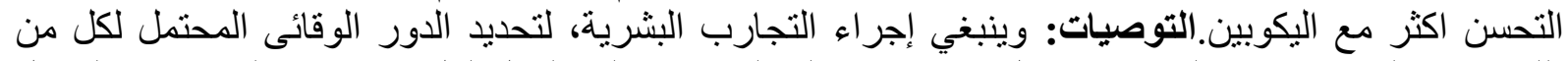

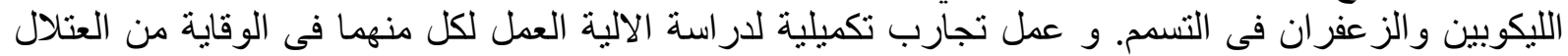

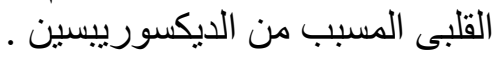

